RE-PARTNERING AS A CONTINGENCY DEDUCTION IN CLAIMS FOR LOSS OF SUPPORT - COMPARING SOUTH AFRICAN AND AUSTRALIAN LAW

ISSN 1727-3781

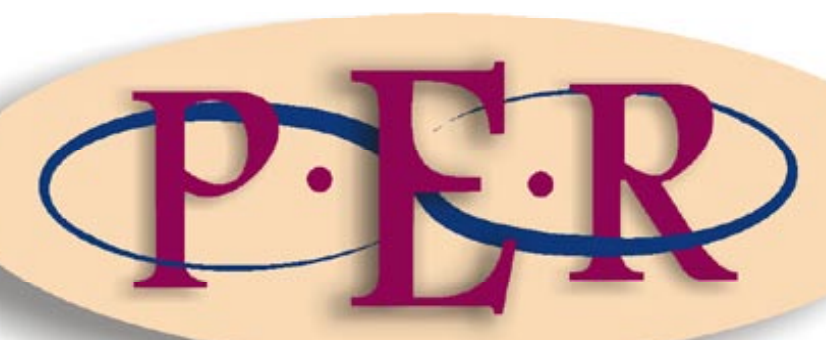

2007 VOLUME 3 


\section{RE-PARTNERING AS A CONTINGENCY DEDUCTION IN CLAIMS FOR LOSS OF SUPPORT - COMPARING SOUTH AFRICAN AND AUSTRALIAN LAW}

\section{Steynberg*}

\section{Introduction}

In South African law a claim for loss of support is based upon the maintenance obligation of the deceased breadwinner in lieu of a relationship of dependency. ${ }^{1}$ Typical examples of such relationships of dependency would include parent and child, husband and wife, grandparents and grandchildren, and brothers and sisters. ${ }^{2}$ In this discussion the focus will fall on the second example mentioned, namely the relationship of dependency between husband and wife. 3 'Actual' dependency, or domestic economic subordination, is not a pre-requisite. ${ }^{4}$ In modern households it is common to find both spouses in the job market earning a salary. The dependent spouse must prove that he or she had a right of support against the deceased and that he or she suffered a loss due to the breadwinner's death. ${ }^{5}$

* B Juris, LL B, LL M, LL D, Associate Professor, Department of Private Law, University of South Africa.

1 Davel Afhanklikes 51-53; Visser and Potgieter Law of Damages 418.

2 Visser and Potgieter Law of Damages 246-247 and n 34.

3 See par 2 below.

4 Carver 2005 QUTLJJ 3. Also see the statement by Gleeson CJ in De Sales v Ingrilli [2002] 212 CLR 338 (HC) 347: "[I]njury can occur in circumstances in which there is no dependency. For example, it is now common for both parties to a legal or de facto marriage to have salaried or income-producing occupations. Each may expect to obtain financial advantage from the other, even where they are both fully able to support themselves from their own income, and are therefore not 'dependent' in any sense."

5 Visser and Potgieter Law of Damages 247. See also Santam Insurance v Fourie 19971 SA 611 (A) in which it was held that the children of a working mother, who had been killed negligently, did not suffer any patrimonial loss due to her death. The mother was under a duty to support her children, but she received more from the household money pool than she had contributed to it. It can therefore not be said that she made any contribution to the maintenance of the children. 
In Australian law the basis of a claim for loss of support is to be found in statutory law. ${ }^{6}$ Legislation exists in all Australian jurisdictions to provide a cause of action against wrongdoers for the benefit of the statutorily defined family of a deceased. The legislation aims to compensate those, who have been deprived of one upon whom they were financially dependent, for the loss of pecuniary support suffered as a result of the death. ${ }^{7}$

In a case where a claim is submitted for loss of support ${ }^{8}$ by the spouse of the deceased breadwinner, the claim will be influenced by the probable remarriage of the surviving spouse. The reason for this is that remarriage gives rise to a new maintenance relationship between the surviving spouse and his or her new marriage partner. ${ }^{9}$ It needs to be stated upfront that the restricted references to 'spouse' and 'remarriage' can no longer be accepted as wide enough to include all relationships of dependency that are recognised in our law. It is suggested that the term 'spouse' be replaced with the term 'partner' and that all references to 'remarriage' be replaced with the term 're-partnering'. The motivation for these suggestions will be given in par 2 below.

It is clear from case law that re-partnering or just the probability of re-partnering has an influence on a claim for loss of support, ${ }^{10}$ but how large the extent of

6 See Supreme Court Act 1995 (Queensland); Fatal Accidents Act 1950 (Western Australia); Civil Law (Wrongs) Act 2002 (ACT); Civil Liability Act 1936 (Southern Australia); Compensation to Relatives Act 1897 (New South Wales); Compensation (Fatal Injuries) Act 1974 (Northern Territories); Fatal Accidents Act 1934 (Tasmania); Wrongs Act 1958 (Victoria).

7 Carver 2005 QUTLJJ 2.

8 In Marine and Trade Insurance $v$ Katz 19794 SA 961 (A) 978-980 Trollip AJ refers specifically to the probability of remarriage as a contingency (or possible eventuality) in a claim for loss of income. The plaintiff was divorced from her husband a few months before the motor-car accident in which she was seriously injured. It does seem strange that the probability of remarriage was mentioned as a contingency in the claim for loss of income. It is rather a contingency which belongs to a claim for loss of support.

9 Davel Afhanklikes 125; Visser and Potgieter Law of Damages 225; Koch Damages for Lost Income 215; Peri-Urban Areas Health Board v Munarin 19653 SA 367 (A) 376D: "Marriage prospects are relevant because marriage would reinstate her right of support"; Constantia Versekeringsmaatskappy v Victor 19861 SA 601 (A) 614C-D. See also Carver 2005 QUTLJJ 2-3 and De Sales v Ingrilli [2002] 212 CLR 338 (HC) on Australian law in this regard.

10 Clair v Port Elizabeth Harbour Board 1886 EDC 311 318; Kennedy v Port Elizabeth Harbour Board (1886) 5 EDC 311; Waring \& Gillow v Sherborne 1904 TS 340 350; Chisholm v East Rand Proprietary Mines 1909 TH 297 302; Hulley v Cox 1923 AD 234 244: "But the object being to compensate them for material loss, not to improve their 
this influence should be, is not always clear. According to Davel, ${ }^{11}$ the demands for fairness, justice and public policy requires that the widow's claim for damages should not be influenced by her remarriage. In line with her sentiments are those who believe that the benefits received from re-partnering, or the probability of re-partnering, ${ }^{12}$ are res inter alios acta and should for this reason not be taken into account in a claim for support. ${ }^{13}$ On the other hand, the opinion expressed by $\mathrm{Koch}^{14}$ is that adjustments for remarriage are reasonable if compensation in a lump sum is understood correctly, namely as a fair price in exchange for the right to litigate further against the defendant. ${ }^{15}$ In spite of these academic opinions re-partnering or the probability of repartnering is taken into account in the quantification of a claim for loss of support.

In this discussion the wider concept of family dependency will be discussed first. Thereafter a distinction will be drawn between the situation where repartnering is an actuality or the intention is real and the situation where repartnering is only a future probability. ${ }^{16}$ Of more practical importance for the quantification process is the distinction drawn by the courts between general and special contingencies, and whether the contingency of re-partnering will be regarded as the one or the other. After discussing this distinction, guidelines will

material prospects, it follows that allowance must be made for such factors as the possibility of remarriage"; Paterson v South African Railways and Harbours 1931 CPD 289 300; De Wet v Odendaal 1936 CPD 103 107; Legal Insurance Company v Botes 19631 SA 608 (A) 617-618; Peri-Urban Areas Health Board v Munarin 19653 SA 367 (A); Snyders v Groenewald 19663 SA 785 (C) 790; Nochomowitz v Santam Insurance 19721 SA 718 (T) 726; Milns v Protea Assurance 19783 SA 1006 (C) 1014.

11 Davel 1989 De Jure 370, 372.

12 In AA Tegel $v$ Madden [1985] 2 NSWLR 591 (SC) 611 Mahoney AJ described the contingency as the capacity to marry and not as the probability of remarriage.

13 Visser and Potgieter Law of Damages 226 n 156 and the authority cited. See par 7 below on the three Australian jurisdictions where the legislature has promulgated legislation forbidding the use of remarriage as a contingency deduction. This is also the position in English law - s 4 of the Fatal Accidents Act 1976. Boberg 1972 SALJ 150 is of the opinion that in a field such as this, where nothing is known and all is surmised, it is better not to speculate at all than to speculate one-sidedly. Also see AA Tegel $v$ Madden [1985] 2 NSWLR 591 (SC) 604-605; Public Trustee v Paniens [1971] 1 SASR 297 (SC) 300: "I think that the suggested deduction, apart from being abhorrent in treating women like cattle to be appraised, is also totally illogical. It is agreed that a woman's revived capacity to earn is not deductible. Why should her revived capacity to remarry be deductible?"

14 Koch Reduced Utility 329.

15 Also see Koch 1986 JCRDL 221.

16 See par 3 and 4 below. 
be given to explain the quantification process that needs to be followed. It is in particular during this process that the South African case law lacks predictability and certainty, and valuable lessons can be learned from Australian law in this regard.

\section{A wider concept of family dependency}

In light of several recent judgments on the extension of the traditional concept of family and 'husband and wife', ${ }^{17}$ as well as the wording of relevant statutes, ${ }^{18}$ it is necessary to change the terminology used to describe relationships of dependency. It is therefore suggested that the wider term 're-partnering' be used, instead of remarriage, whenever reference is made to a new relationship of dependency which could lead to a duty of support between the partners in this relationship. It should also be noted that these relationships could be heterosexual or homosexual. ${ }^{19}$ A duty of support is only acknowledged in the case of formally recognised relationships, which will now in terms of the new Civil Unions Act 17 of 2006 also include registered civil partnerships. It is thereby acknowledged that benefits from all recognised forms of 're-partnering' should be included in a fair determination of the extent of the loss of support.

17 Satchwell v President of the RSA 20026 SA 1 (CC); Du Toit v Minister of Welfare and Population Development 20032 SA 198 (CC); J v DG, Department of Home Affairs 20035 BCLR 463 (CC); Robinson v Volks [2004] 2 All SA 61 (C); Amod v Multilateral Motor Vehicle Accident Fund (Commission for Gender Equality Intervening) 19994 SA 1319 (SCA); Santam v Henery 19993 SA 421 (A); Mlisane v South African Eagle Insurance 19963 SA 36 (C); Zimnat Insurance v Chawanda 19912 SA 825 (ZS); Du Plessis v RAF 20041 SA 359 (SCA).

18 See par 7 below for the wording of three Australian statutes. In SA law the new Civil Unions Act 17 of 2006 is relevant. Also see s 31 of the Black Laws Amendment Act 76 of 1963 and the Recognition of Customary Marriages Act 120 of 1998.

19 See Robinson v Volks [2004] 2 All SA 61 (C) and Du Plessis v RAF 20041 SA 359 (SCA). Also see Australian statutory amendments to include same-sex partners - $s 83$ of the Discrimination Law Amendment Act 2002 (Queensland); s 57 of the Acts Amendment (Equality of Status) Act 2003 (Western Australia); s 60 of the Law Reform (Gender, Sexuality and De facto Relationships Act 2003 (Northern Territory); s 4 of the Wrongs (Dependants) Act 1982 (Victoria); sch 1 of the Relationships (Consequential Amendments) Act 2003 (Tasmania); sch 2.3 of the Property (Relationships) Legislation Amendment Act 1999 (New South Wales); s 23 and 28(2) of the Civil Law (Wrongs) Act 2002 (Australian Capital Territory). 
The probability of remarriage or re-partnering obviously does not only apply to women, but can also be raised in the case of male claimants, should circumstances warrant it. ${ }^{20}$ In Australian law the courts usually refer to the 'marriageability' of the surviving spouse when determining the chances of remarriage or re-partnering. Age and conventional good looks have traditionally been used as markers of the marriageability of women. ${ }^{21} \mathrm{~A}$ man who is economically dependent on his deceased wife finds himself in the same position, but such a case is much more uncommon and a man's physical attractiveness has never, according to the author's knowledge, been considered in South African or Australian case law. ${ }^{22}$ In spite of acknowledging that re-partnering as a contingency deduction should be gender-neutral, most of the examples and references in this discussion are of widows claiming for loss of support. If reference is made to a widow in this discussion, it should therefore be understood that this reference is used only for practical reasons, and that it includes all other partners in recognised relationships of dependency.

\section{$3 \quad$ Actual or intended re-partnering}

If the widow has already remarried or entered into a new relationship during the course of the trial, this occurrence is taken into account as a proven fact $^{23}$ and no longer as a contingency, ${ }^{24}$ which is naturally characterised by uncertainty. ${ }^{25}$

20 Davel Afhanklikes 127; Koch 1964 SALJ 216 and n 28; Koch Damages for Lost Income 217; Koch Reduced Utility 329; Carver 2005 QUTLJJ 7; Luntz and Hambly Torts 632; Cooke and Cooke v Maxwell 1942 SR 133 136; Herman v Johnston [1972] WAR 121124.

21 See De Sales v Ingrilli [2002] 212 CLR 338 (HC) 365: "Seldom, if ever, will a court be able to make any useful prediction about whether, or when, one human being will form a close emotional attachment with another...And it is never assisted by fastening upon some superficial characteristics labeled as 'appearance', 'personality', 'credentials' or the like and having the judge or jury base on those characteristics some estimate of 'marriageability'."

22 Atkinson 2003 QUTLJJ 5/10.

23 See Davel 1989 De Jure 370, 372. Also see Faulkner v Keffalinos [1970] 45 ALJR 80 (HC) 85: "If in fact any of such things occurs before the assessment has to be made, what would have been allowed for as a possibility has become an actuality: the risk of an interruption of earnings has materialized and a hypothetical deduction to be made in the computation of damages has crystallized."

24 Apart from the three Australian jurisdictions mentioned in par 7 below. 
According to Carver ${ }^{26}$ the impact of a claimant's actual or intended repartnering on the assessment of the loss of support claim should be considered for the following reasons: (a) preference for certainty over speculation; (b) compensation as an overarching concept; and (c) preventing illogical outcomes. $^{27}$

The financial benefit that the widow receives through re-partnering is taken into account in calculating damages according to the theory on compensating advantages. ${ }^{28}$ The new relationship does not, however, necessarily mean that the widow automatically loses her right to a claim for loss of support. ${ }^{29}$ The income of the new partner and his life expectancy will be taken into account in the calculation of the extent of her claim. ${ }^{30}$ If the new partner is not able to support the widow at the same level as the deceased, the loss to the widow is deemed to continue beyond the date of the new relationship, though it is

25 See Steynberg Gebeurlikhede 23-24 for a reference to the characteristics of a contingency.

26 Carver 2005 QUTLJJ 4-5.

27 See Budget Rent-A-Car Systems v Van der Kemp [1984] 3 NSWLR 303, 311.

28 Koch Reduced Utility 325: "If the value of prospective benefits from the new marriage exceeds the value for old marriage then the widow has gained. There is no reason why this gain should not be offset against her past loss of support up to the date of remarriage". Also see AA Tegel $v$ Madden [1985] 2 NSWLR 591 (SC) 604-605.

29 In Glass v Santam Insurance 19921 SA 901 (W) a widow remarried eighteen months after her husband's death and got divorced three months later. Two years later and one year before the commencement of this hearing the widow married her third husband. The plaintiff argued that she nevertheless suffered a loss of support due to the death of her first husband, because her third husband was considerably less affluent than her first deceased husband. The Witwatersrand Local Division, however, determined that the widow's right to claim for loss of support lapsed with her remarriage. The decision in Glass drew much criticism and was overturned seven years later by the Supreme Court of Appeal in Ongevallekommissaris v Santam 19991 SA 251 (SCA) 259. The court held that the remarriage of the widow before the hearing did not automatically dismiss her claim for loss of support. This factual happening will, however, play a role in the assessment of her damages.

30 Davel Afhanklikes 126; De Wet v Odendaal 1936 CPD 103 107; Roberts v London Assurance (3) 19482 SA 841 (W) 850; Legal Insurance Company v Botes 19631 SA 608 (A) 618; De Sales v Ingrilli [2002] 212 CLR 338 (HC) 352. Also see Goodburn v Thomas Cotton [1968] 1 QB 845 (CA) 854: "It does not necessarily follow that if a widow remarries, so far as dependency is concerned, her right to financial support from those who killed her husband necessarily comes to an end. Matters like the means of the new husband, or the potential husband, have to be considered. The question whether the marriage will last has to be considered. All the manifold chances and changes of life have to be considered. It is indeed a task which many judges have disliked and many people have said that judges ought not to be called upon to perform." 
reduced by whatever support is likely to be obtained from the second or a subsequent partner. ${ }^{31}$

\section{$4 \quad$ Re-partnering as a future probability}

In applying re-partnering as a contingency, the court must firstly determine the probability of a subsequent re-partnering, ${ }^{32}$ and for this the court must consider the facts known at the time of the hearing. Davel ${ }^{33}$ refers to the following relevant facts based on South African case law: The age of the widow; ${ }^{34}$ her character and appearance; ${ }^{35}$ how long the deceased was happily married to her; ${ }^{36}$ the fact that she must provide for small children and that this limits social interaction; ${ }^{37}$ the fact that the widow may already have an intimate friend at the

31 Luntz and Hambly Torts 632. Also see Hollebone $v$ Greenwood (1968) 71 SR (NSW) 424 (CA).

32 See Koch 1986 JCRDL 217: "A wife has at all times during her marriage the prospect that at some time her husband may predecease her and that she may remarry and derive financial benefit from a second marriage. While her husband lives the value of this chance is small. It may even be negligible, if not non-existent, for older wives and others whose remarriage prospects might for religious or other reasons be somewhat restricted. For many wives the fact of the death of the husband brings about a massive increase in the chance of remarriage and an according increase in the financial value of that chance. In the computation of damages it is the enhanced value of this chance which is being deducted when allowance is made for the remarriage prospects of the widow. If the widow has in fact remarried, then one may adduce evidence not only of this fact but also of the financial standing of the new husband."

33 Afhanklikes 125-126; Davel 1989 De Jure 370.

34 Chisholm v East Rand Proprietary Mines 1909 TH 297 302; Bester v Silva Fishing Corporation 19521 SA 589 (C) 600; Trimmel v Williams 19523 SA 786 (C) 793; Munarin v Peri-Urban Areas Health Board 19651 SA 545 (W) 557; Snyders v Groenewald 19663 SA 785 (C) 790; Milns v Protea Assurance 19783 SA 1006 (C) 1014; Shield Insurance v Booysen 19793 SA 953 (A) 966C-E.

35 Paterson v South African Railways and Harbours 1931 CPD 289 300: "The plaintiff is a young and comely woman aged 29 and the prospect of her remarrying must be taken into consideration"; De Jongh v Gunther 19754 SA 78 (W) 81-84; Roberts v London Assurance (3) 19482 SA 841 (W) 850; Bester v Silva Fishing Corporation 19521 SA 589 (C) 600; Trimmel v Williams 19523 SA 786 (C) 793; Legal Insurance Company v Botes 19631 SA 608 (A) 617-618; Munarin v Peri-Urban Areas Health Board 19651 SA 545 (W) 557; Snyders v Groenewald 19663 SA 785 (C) 790; Nochomowitz v Santam Insurance 19721 SA 718 (T) 725; Milns v Protea Assurance 19783 SA 1006 (C) 1014; Shield Insurance $v$ Booysen 19793 SA 953 (A) 966C-E; Burns v National Employers General Insurance 19883 SA 355 (C) 364H; De Sales v Ingrilli [2002] 212 CLR 338 385: "[A]n evaluation of physical attractiveness is not normally made in the case of male claimants"; Luntz and Hambly Torts 632.

36 Legal Insurance Company v Botes 19631 SA 608 (A) 618.

37 De Wet v Odendaal 1936 CPD 103 107; Bester v Silva Fishing Corporation 19521 SA 589 (C) 600; Legal Insurance Company v Botes 19631 SA 608 (A) 617; Munarin v Peri-Urban Areas Health Board 19651 SA 545 (W) 557; Snyders v Groenewald 19663 SA 785 (C) 
time of the trial; ${ }^{38}$ the widow's point of view on a subsequent marriage; ${ }^{39}$ the fact that the damages received for loss of support may better her chances at another marriage; ${ }^{40}$ census surveys and statistics indicating what percentage of widows (of her age) will remarry; ${ }^{41}$ the respect the widow had for the deceased; ${ }^{42}$ and the general welfare and health of the widow. ${ }^{43}$ According to Davel $^{44}$ the court and not an actuary, is in a better position to consider the above-mentioned factors in order to determine the probability of a remarriage or re-partnering. ${ }^{45}$

790; Shield Insurance v Booysen 19793 SA 953 (A) 966C-E. See Boberg 1964 SALJ 218 n 43: "I devote no time to consideration of the likelihood of a widow with seven children remarrying."

38 Shield Insurance $v$ Booysen 19793 SA 953 (A) 962E; Willis $v$ The Commonwealth (1946) 73 CLR 105; AA Tegel v Madden [1985] 2 NSWLR 591; Dominish v Astill [1979] 2 NSWLR 368 393-394; Mahoney v Dewinter (unreported, Supreme Court of Queensland, Court of Appeal, 15 March 1993).

39 Legal Insurance Company v Botes 19631 SA 608 (A) 617; Shield Insurance v Booysen 19793 SA 953 (A) 966C-D; Masiba v Constantia Insurance 19824 SA 333 (C) 344-345. Koch Reduced Utility 328 comments that the courts do not attach much value to a white widow's opinion about her remarriage possibilities, while they do in the case of black women. Such an approach would necessarily be contentious on the basis of the fairness principle in the Constitution of the Republic of South Africa 1996. A similar unfair distinction made between male and female plaintiffs was observed by Carver 2005 QUTLJJ 7 in Australian case law. In Rodda v Boontjie (unreported, Supreme Court of Queensland, 27 May 1993) Byrne J allowed a 45 percent combined discount for general contingencies and re-partnering prospects, notwithstanding evidence of the widow's disinterest in re-partnering after being assaulted and robbed by a subsequent de facto partner. However, in Kuhlewein v Fowke [2000] QSC 404 (unreported, 10 November 2000), Mullins $\mathrm{J}$ made no deduction for prospective future financially beneficial repartnering, although the widower in question had remarried and separated before trial. The court accepted that the widower's adamant testimony that he would not re-partner was influenced by the failure of his second marriage. In Knight $v$ Anderson (1997) 17 WAR 85 the Western Australian Supreme Court rejected an argument that a claimant's pregnancy subsequent to her husband's death falsified testimony that she would never re-partner.

40 Roberts v London Assurance (3) 19482 SA 841 (W) 850; Trimmel v Williams 19523 SA 786 (C) 793; Burns v National Employers General Insurance 19883 SA 355 (C) 364. Contra Koch Damages for Lost Income 217: "[]]t would be inappropriate for the court to take account of the effect on the prospects of remarriage of the payment of compensation."

41 Chisholm v East Rand Proprietary Mines 1909 TH 297 302; Smart v SAR\&H 1928 NPD 361 365; Roberts $v$ London Assurance (3) 19482 SA 841 (W) 850; Legal Insurance Company v Botes 19631 SA 608 (A) 617; Snyders v Groenewald 19663 SA 785 (C) 790. See Koch Reduced Utility 327 for a discussion of the use of statistics for the probability of remarriage by black women.

42 Snyders v Groenewald 19663 SA 785 (C) 790; Nochomowitz v Santam Insurance 19721 SA 718 (T) 726.

43 Legal Insurance Company v Botes 19631 SA 608 (A) 618; Snyders v Groenewald 19663 SA 785 (C) 790.

44 Davel Afhanklikes 126.

45 See Thomson 1988 De Rebus 68: "In the courts, the amount of the deduction is subjectively determined, after consideration has been given to such matters as the widow's appearance, her personality, her financial circumstances, the number of children 
In AA Tegel Pty Ltd v Madden ${ }^{46}$ the Australian Supreme Court held that support from a de facto relationship should also be taken into account in the reduction of the plaintiff's loss of support from the deceased:

[I]t may be suggested that a de facto relationship is less likely to endure (or to endure for as long) as where the parties have entered into marriage. But just as courts have hitherto looked to declarations of intent to marry before the trial and to the fact of marriage before the trial, I believe they may look to other relationships akin to marriage both to ascertain the loss that has in fact been suffered to the date of the trial and to attempt the realistic evaluation of the likely extent of the loss into the future. ${ }^{47}$

With the above quotation in mind, one could rightly ask the question whether possible benefits from informal or de facto heterosexual and homosexual relationships should not also be taken into account in the quantification of a claim for loss of support. In terms of the new Civil Unions Act 17 of 2006 all monogamous relationships, whether homosexual or heterosexual, has the potential to be recognised some time in the future (once the partners choose to make use of the registration procedures) and for this reason benefits from these relationships should in principle also be taken into account.

\section{Quantification of re-partnering as a probability}

Once the court has, as a first step, completed the value judgment on the probability of re-partnering, the court needs to quantify this probability. Case law indicates a high level of uncertainty about how to quantify re-partnering as a contingency. The main reason for this is that the facts of each case are

and whatever else the judge may consider relevant. It is, however, customary for the actuary to give expert evidence on the amount, not only of the value of the widow's loss of support, but also on the amount of the deduction to be made for the possibility of her remarriage"; Howroyd and Howroyd 1958 SALJ 74: "It is not usually possible for the actuary to enter into such delicate matters as the personal appearance and temperament of the widow - this is by tradition the prerogative of the judge - but in exceptional cases where the widow had, for example, been badly scarred, some adjustment to the deduction based upon averages is clearly required."

46 AA Tegel v Madden [1985] 2 NSWLR 591 (SC) 605.

47 Also see Luntz and Hambly Torts 632. 
unique, so that one cannot attach much value to precedent. The endeavour remains to identify and provide guidelines from case law with as purpose, a more consistent and morally justifiable quantification of re-partnering as a contingency.

The courts, in most cases, will either reduce the contingency to an amount, ${ }^{48}$ or they will express the value of the contingency as a percentage of the value of the loss of support. ${ }^{49}$ Where the court during the initial step considered facts, it is now obliged to venture 'guesses' in terms of the quantification process. According to $\mathrm{Koch}^{50}$ the court must give consideration to two factors during this process, namely the expected amount of years that the plaintiff will remain without a formal partner ${ }^{51}$ and the financial position of her next partner. ${ }^{52}$ Should these factors not be specifically mentioned in court, something that incidentally happens frequently, it creates the impression that the court has not given these two factors any consideration at all. Koch warns that the

...factors which influence the judicial assessment of the average duration of widowhood are commonly highly speculative and the court, it is respectfully submitted, should be astute not to allow minor considerations to assume undue weight. ${ }^{53}$

In respect of the financial position of the next partner, it is expected that the widow would re-partner into the same social class as before and that her financial circumstances would also be similar to what she had with her previous partner. ${ }^{54}$ If the widow's deceased partner had been a very wealthy man ${ }^{55}$ or a

48 Clair v Port Elizabeth Harbour Board 1886 EDC 311 318; Chisholm v East Rand Proprietary Mines 1909 TH 297 302; Paterson v South African Railways and Harbours 1931 CPD 289 300; Lamb v Brandt [1984] 56 BCLR 74 (CA) 85.

49 See Nochomowitz $v$ Santam Insurance 19721 SA 718 (T) 726 where a mere two percent deduction was made and Milns v Protea Assurance 19783 SA 1006 (C) 1014 where seventy percent was deducted.

50 Koch Damages for Lost Income 215.

51 See Koch Reduced Utility 325-326.

52 Roberts v London Assurance (3) 19482 SA 841 (W) 850; Gillies v Hunter Douglas [1963] QWN 31; Hollebone v Greenwood [1968] 71 SR 424 (NSW) 430.

53 Koch Damages for Lost Income 216.

54 Ibid 17; Burns v National Employers General Insurance 19883 SA 355 (C) 364I; De Sales v Ingrilli [2002] 212 CLR 338 (HC) 378: "But difficult as this always has been, and probably always will be, it seems a reasonable assumption that, in the majority of cases, the plaintiff will obtain the kind of support that he or she obtained from the deceased." 
very poor one, it would obviously influence the court's general expectation as explained above. ${ }^{56}$ The onus of proof rests on the defendant to prove the extent to which the widow will be financially benefitted by re-partnering. ${ }^{57}$

Milns $v$ Protea Assurance Co $L t d^{58}$ is one of the best examples in South African case law of the unfair result that contingency deductions can have if they are not judiciously applied. The widow was young and she and the deceased did not have children. Firstly, Watermeyer $\mathrm{J}$ found that a general contingency deduction of twenty-two percent should be made in lieu of the uncertainties that her future could hold. The result was that her claim of R130 000 was reduced to $\mathrm{R} 101,400.00$. He further found that "she is a very presentable young lady with no attachments and ... . [I] rate her chances of remarriage as high". Based on this, he subtracted a further seventy percent from her claim, which left her with an amount of R30,420.00. The message the judge sent to this particular widow was that she should remarry as soon as possible in order to survive and that she should also marry a man with the same or better substance as the deceased. In reality the two deductions made by the court imply close to an eighty percent adjustment. Circumstances should have been very unusual to validate such a high adjustment, but apparently this was not the case in this instance. The financial position of the potential new spouse was also erroneously not taken into consideration by the court.

55 In Roberts $v$ London Assurance (3) 19482 SA 841 (W) 850 Dowling J took into consideration that the deceased "was a man of earning powers above the average in his walk of life and that a second husband would probably not be so effective a wage earner". Based on this he reduced the deduction for the widow's probable remarriage from a third to twenty five percent.

56 See Koch Reduced Utility 328-329; Howroyd and Howroyd 1958 SALJ 74: "An assumption which is implicit in the use of the average deduction is that by remarriage the widow will be afforded the same degree of support as she received from her deceased husband. In certain circumstances this might be a quite invalid assumption".

57 See De Sales v Ingrilli [2002] 212 CLR 338 (HC) 378: "[T] he defendant has the onus of establishing the benefits that may be obtained from future financial support. If the evidence suggests that the surviving spouse may not receive the same level of support from an existing or future relationship, it is the defendant who must bear the consequences." 
In Shield Insurance Co Ltd v Booysen ${ }^{59}$ appeal Trollip J distinguished between the position of the widow in this case and that of the widow in Milns, where the first-mentioned was slightly older and had three children as well as an illegitimate child. Based on these facts he confirmed the finding of the trial court that 'only' a fifty percent deduction was necessary under the circumstances. ${ }^{60}$ The fact that the widow in this case acknowledged that she would remarry, should the opportunity arise to meet the right man, probably resulted in the heavier weighting given in the determination of the range of the contingency adjustment.

Also in Burns v National Employers General Insurance Co $L t d^{61}$ the court found that the widow's claim for loss of support had to be reduced by twenty percent for general contingencies, which inter alia included the probability of divorce. Thereafter her claim was reduced by a further forty percent in lieu of the probability of remarriage.

Trimmel $v$ Williams ${ }^{62}$ provides another example of a particularly high deduction for remarriage amounting to approximately seventy percent. The court based this deduction on the following grounds: The claimant was a widow with capital; provision had already been made for the children; she was young and beautiful and there was a probability that she would remarry. Once again there was an oversight in that no mention was made of the financial position of the second husband.

59 Shield Insurance $v$ Booysen 19793 SA 953 (A) 966C-F.

60 Also see Lebona $v$ President Versekeringsmaatskappy Bpk 19913 SA 395 (W) 398F-G where a fifty percent contingency adjustment was made for remarriage. On the other hand, the decision made by Holmes AJ in Anthony $v$ Cape Town Municipality 19674 SA 445 (A) $45 \mathrm{~F}$ was that "[o]ne is inclined to exclude any reasonable possibility of her re-marriage: it would need an heroic suitor to plight his troth to an unendowed widow beset with a quiverful of children".

61 Burns v National Employers General Insurance 19883 SA 355 (C) 364G-J.

62 Trimmel $v$ Williams 19523 SA 786 (C) 793A-E. 
The incorporation of statistics to quantify the probability of re-partnering must be handled with due caution by the courts. In Legal Insurance Company Ltd $v$ Botes $^{63}$ Holmes AJ found that statistics of remarriage

...should not be regarded as a starting point, but merely as one of the facts, to be considered along with all the other facts - one of which is that Cupid is notoriously incorrigible and unpredictable.

In Snyders $v$ Groenewald ${ }^{64}$ Van Winsen J refers to various relevant factors, among others the fact that that the widow had four young children, as well as that her statistical probability of remarrying at the age of thirty-nine was determined at forty-two percent. Taking all of the above into consideration, his finding was that a twenty percent contingency deduction for her probable remarriage had to be made.

$\mathrm{Koch}^{65}$ is of the opinion that as soon as a widow receives a large sum of money as compensation, it heightens her chances of re-partnering above the average. ${ }^{66}$ For this reason the contingency adjustment for re-partnering should be greater than currently suggested by statistics. ${ }^{67}$ It seems, however, as if courts are opposed to using statistics on re-partnering. ${ }^{68}$ In spite of this $\mathrm{Koch}^{69}$ regards statistics as a useful objective method of dealing with the clear subjective considerations of the courts on the probability of re-partnering. ${ }^{70}$

63 Legal Insurance Company v Botes 19631 SA 608 (A) 617G-H.

64 Snyders v Groenewald 19663 SA 785 (C) 790A-H.

65 Koch Reduced Utility 326.

66 Roberts v London Assurance (3) 19482 SA 841 (W) 850; Trimmel v Williams 19523 SA 786 (C) 793C-D; Burns v National Employers General Insurance 19883 SA 355 (C) 364H.

67 See Thomson 1988 De Rebus 70.

68 Legal Insurance Company v Botes 19631 SA 608 (A) 617; Schiffmann v Jones (1970) 70 SR 455 (NSW) 463-469; De Sales v Ingrilli [2002] 212 CLR 338 (HC) 365: "Statistics may provide some basis for saying, in some cases, that it is more probable than not that, at some time after (say) 20 years a surviving spouse will for a new relationship. The younger the survivor, the more likely may that be to occur. But, in very many cases, statistics will provide little useful guidance about the time by which it is more probable than not that it will occur."

69 Koch Reduced Utility 327-328.

70 Ibid 328: "One must in any event express serious reservations about the subjective judicial assessment of remarriage prospects for widows from unfamiliar cultural backgrounds. White remarriage rates are very high compared to other social groups in South Africa and a white judge should be wary of overstating the remarriage prospects of a black widow." Also see Masiba v Constantia Insurance 19824 SA 333 (C) 344-345. 
It can be stated that courts should be wary to regard statistics on the probability of re-partnering as a guideline, or even as a point of departure, in the determination of adjustments, but should rather regard it merely as one of the multiple factors that must be considered. ${ }^{71}$

In general it can be stated that South African courts tend to give serious consideration to the probability of a widow re-partnering and they are inclined to make substantial accommodation for this. It is nevertheless true that the proven factual circumstances do not always warrant these high adjustments, especially if they are preceded by a general contingency adjustment. ${ }^{72}$

\section{Re-partnering as a general or special contingency}

The distinction between general and special contingencies justifies a discussion on its own, ${ }^{73}$ but for purposes of this discussion the following brief summary has to suffice: ${ }^{74}$

(1) General contingencies are regarded as general for the reason that they could be present in the lives of all people at any time, for

71 Legal Insurance Company v Botes 19631 SA 608 (A) 617: "[S]tatistics . . should not be regarded as a starting point, but merely as one of the facts, to be considered along with all the other facts - one of which is that Cupid is notoriously incorrigible and unpredictable"; De Sales v Ingrilli [2002] 212 CLR 338 (HC) 364-365 par 70: "Statistics may throw some light on some of the questions we have mentioned. . . But great care must be exercised in their use. What are the characteristics reflected in the statistics? Are those relevant to the present inquiry? Why can it be assumed that the individual will conform to the average? To apply a statistical average to an individual case assumes that the case has all the characteristics which, blended together, create the statistic."

72 It is also inappropriate to make an adjustment for re-partnering as contingency together with another contingency, as was the case in Paterson $v$ South African Railways and Harbours 1931 CPD 289 300. Sutton J reduced the widow's claim for loss of support with fifty percent, taking into account her probable remarriage as well as the probability that the deceased would not have received all the increases which were incorporated into the calculations. It would in particular be problematic if an appeal were to be lodged against such a contingency adjustment.

73 See in general Koch Reduced Utility 149-162; Boberg 1964 SALJ 201-203; De Jongh v Gunther 19754 SA 78 (W) 80H; Milns v Protea Assurance 19783 SA 1006 (C) 1011E-F; Shield Insurance $v$ Booysen 19793 SA 953 (A) 965F-966F; Parity Insurance $v$ Van den Bergh 19664 SA 463 (A) 477C-D; McIntosh v Williams [1979] 2 NSWLR 543 (SC) 554558; De Sales v Ingrilli [2002] 212 CLR 338 (HC) 348-349. 
example death or sickness; specific contingencies are regarded as specific because they are primarily relevant in specific people's lives at specific times, for example re-partnering or divorce.

(2) General contingencies need in general not be proven, whereas specific contingencies have to be substantiated by evidence, although not necessarily proven on a preponderance of probabilities.

(3) A general contingency deduction is usually low (at average ten per cent), whereas a contingency deduction for specific contingencies fluctuates (between five and fifty per cent) depending on the evidence and circumstances of the plaintiff.

If one strictly applies the above-listed distinctions to re-partnering it has to be categorised as a specific contingency. The following two important guidelines should, however, be applied: (1) Evidence must be presented to validate repartnering as a specific contingency and (2) the percentage deduction for repartnering must be in proportion to the probability of its occurrence.

\section{$7 \quad$ Re-partnering as a contingency deduction in Australian law}

In three Australian jurisdictions the legislature has promulgated legislation forbidding the use of re-partnering as a contingency deduction in a claim for loss of support. ${ }^{75}$ These three jurisdictions are the Northern Territories, $^{76}$ Victoria $^{77}$ and Queensland. ${ }^{78}$ The wording of these regulations is sufficiently

75 Also see s 4 of the Fatal Accidents Act 1976 in English law where similar provisions can be found.

76 S 10(4) of the Compensation (Fatal Injuries) Act 1974: "In assessing damages in action, no reduction shall be made on account of $-(h)$ the marriage or entry into a de facto relationship, or the prospects of doing so, of a surviving spouse or de facto partner or a surviving former spouse or de facto partner."

$77 \mathrm{~S}$ 19(2) of the Wrongs Act 1958: "In assessing damages in an action under this Part, that is commenced on or after the commencement of the Wrongs (Remarriage Discount) Act 2004 , no separate reduction may be made on account of - (a) the remarriage or formation of a domestic partnership; or (b) the prospects of remarriage or formation of a domestic partnership - of the surviving spouse or domestic partner, or a surviving former spouse or former domestic partner, of the deceased person." 
wide to include both the traditional concept of marriage as well as other nonformal relationships. In section 10(4)(h) of the Compensation (Fatal Injuries) Act 1974 (Northern Territories) reference is made to marriage and entry into a de facto relationship. In section 19(2) of the Wrongs Act 1958 (Victoria) reference is made to remarriage and the formation of a domestic partnership, and section 23A(2) of the Supreme Court Act 1995 (Queensland) refer to any new relationship. These prohibitions relate to not only instances where remarriage or other relationships are a mere probability in the future, but also to instances where it is a real or definite possibility. One could argue that in instances where re-partnering with real benefits has already taken place before the date of trial, the application of these statutory prohibitions will lead to double compensation. It is for this reason not suggested that similar statutory prohibitions be envisaged for South Africa, but rather that the judiciary applies it's discretion in a fair manner according to the guidelines suggested at the end of this discussion.

Apart from the three mentioned jurisdictions in Australia regulated by statute, the legal position in Australian law on re-partnering as a possible contingency deduction is to be found in case law, as is the case in South Africa. In a recent decision of the Australian High Court in De Sales $v$ Ingrilli ${ }^{79}$ justice Kirby pointed out the changeability of the Australian judicial bench when it comes to the quantification of re-partnering as a probability or contingency. ${ }^{80}$ Contingency adjustments for re-partnering in Australian case law vary from two percent $^{81}$ to one hundred percent. ${ }^{82}$

78 S 23A of the Supreme Court Act 1995: "(2) The court must not take into account any financial benefits that the spouse may receive as a result of a new relationship that the spouse may enter into after the assessment. (3) Subsection (2) applies even if the spouse intends to enter into a new relationship."

79 De Sales v Ingrilli [2002] 212 CLR 338 (HC) 391-392 par 150.

80 Ibid par 151: "It might be argued that these variations merely demonstrate the infinite variety of circumstances proved in, or inferred from, the evidence of a particular case. However, another explanation may be that the estimation depends upon imponderable factors, that it relies too much on considerations of the personalities and attitudes of the judges or juries, typically after a short encounter with the plaintiff, when they engage in the re-partnering 'guessing game'."

81 See Cremona v RTA [2000] NSWSC 556 par 64.

82 See Willis v The Commonwealth (1946) 73 CLR 105 (HC). 


\section{In Dominish $v$ Astill ${ }^{83}$ Reynolds AJ declares that a position of moderation} should be taken in terms of re-partnering in order to avoid acting unfairly towards the widow. In the recent decision in the High Court of Australia in De Sales $v$ Ingrilli, ${ }^{84}$ this position of moderation was formulated comprehensively. Chief justice Gleeson distinguished between cases where the claimant had already remarried (re-partnered) and cases where remarriage (re-partnering) had not yet occurred. In the instance where remarriage had occurred, or where a marriage with a specific person was a definite prospect, the court could examine the circumstances of the particular case and make appropriate adjustments. ${ }^{85}$ Therefore, the remarriage did not automatically exclude the right to support.

Where remarriage had not yet occurred, a double contingency had to be addressed: Firstly, the probability that the claimant would remarry and secondly, the probability that financial advantage would flow from this union. Chief justice Gleeson was of the opinion that the court's subjective adjudication of both these contingencies would be speculative in nature and that even statistics would not sufficiently assist the court. ${ }^{86}$ The fact that these

83 Dominish v Astill [1979] 2 NSWLR 368 (CA) 378F-G: "It has come to be accepted, and in my opinion correctly, that, although real and not nominal allowance should be made for the revived capacity to marry, such allowance should, in general, be moderated for fear of otherwise doing an injustice to the widow."

84 De Sales v Ingrilli [2002] 212 CLR 338 (HC) 352-353 par 27-31.

85 Luntz Assessment of Damages 541: "[I]t is not the fact of remarriage, but the quality of the support to be derived from the new spouse, that is relevant to the assessment of damages. The court is entitled to take account of the means and circumstances of the second spouse, the likelihood of the support continuing and even the possibility of a third marriage and support from it. Thus even if, as in the case of a young widow, there is a strong likelihood of remarriage, allowance may be made in appropriate circumstances for the fact that the second marriage may not be financially so advantageous." See Willis $v$ The Commonwealth (1946) 73 CLR 105 (HC); Dominish v Astill [1979] 2 NSWLR 368 (CA) 378B-C; Hewitt v Tonkin [2003] WADC 203 par [21] (unreported, 29 September 2003).

86 Also see De Sales v Ingrilli [2002] 212 CLR 338 (HC) 365: "Seldom, if ever, will a court be able to make any useful prediction about whether, or when, one human being will form a close emotional attachment with another. Statistics may provide some basis for saying, in some cases, that it is more probable than not that, at some time over (say) the next 20 years a surviving spouse will form a new relationship. The younger the survivor, the more likely may that be to occur. But, in very many cases, statistics will provide little useful guidance about the time by which it is more probable than not that it will occur." In Jones $v$ Schiffmann [1971] 124 CLR 303 (HC) 306 Barwick CJ specifically referred to statistics on remarriage and he held the opinion that they were irrelevant in claims for loss of support. Luntz Assessment of Damages 542 too doubts the accuracy of statistics on remarriage. See in contrast Dominish v Astill [1979] 2 NSWLR 368 (CA) 391E-G: "These [statistics], in 
contingencies were unpredictable, did not however release the courts from the obligation to take this into account. According to him, the uncertainties involved in the probability of remarriage were not greater or smaller than those apparent in other 'vicissitudes of life' such as unemployment, which usually forms part of a general contingency adjustment. ${ }^{87}$

The majority finding of the court by justice Kirby ${ }^{88}$ was that in cases where remarriage has not yet occurred, remarriage or re-partnering could no longer be applied as a specific contingency, which tends to be higher than the general contingency adjustment. However, it was held that the degree to which economic advantages or disadvantages of hypothetical re-partnering remained relevant in the calculation of the loss suffered as a result of the death of the breadwinner, it should now be taken into consideration as part of the 'standard' adjustment (general contingency adjustment) for uncertain future events. The High Court determined that the general contingency adjustment, which incorporated re-partnering, should only be five percent: ${ }^{89}$

Re-partnering is merely another of the many possible vicissitudes of life, namely that the claimant may enter an economically beneficial or detrimental relationship after the trial. It is therefore to be given no more weight than any of the other vicissitudes that go to make up the general discount. The 'standard' adjustment should not be increased to re-introduce the 'remarriage' discount by the back door. ${ }^{90}$

my opinion, provide some assistance. I recognize, of course, that they can be used only as a guide to the statistically average, and must yield to the circumstances which govern the case under consideration. They do, however, indicate that the average rate of remarriage for say widows under thirty years of age, is high rather than low; and that, on the average, a widow under thirty has a better than even chance of remarrying within ten years. I see no reason why figures of this kind should not be used, with discretion and appreciation of their inadequacies, to provide a statistical context for the inquiry."

87 De Sales v Ingrilli [2002] 212 CLR 338 (HC) 354: "Allowance is to be made for the contingency of a financially beneficial remarriage, in the same way as allowance is made for the contingency of premature death, injury, unemployment or financial ruin. It is a chance which usually cannot be predicted with any degree of certainty in a particular case, but which, in the population as a whole, is not a chance that can be disregarded as insignificant."

88 De Sales v Ingrilli [2002] 212 CLR 338 (HC) 396-397: "The accurate assessment of economic benefits and losses from a hypothetical future relationship has been shown to be impossible and undesirable. What has been known as the discount for the prospects of remarriage is therefore no longer part of the law."

89 Ibid at 397.

90 See, however, the minority judgment of McHugh J in De Sales $v$ Ingrilli [2002] 212 CLR 338 (HC) 378-388: "Accordingly in my view, this Court should not abolish the long $19 / 25$ 


\section{Conclusion}

The uncertainty and unpredictability in South African law with regards to the quantification of re-partnering as a contingency in a claim for loss of support can to a certain extent be addressed if the more moderate position of the latest Australian case law is followed. In terms of this 'moderate' position repartnering should be regarded as a general contingency if it has not taken place at the time of quantification. As part of the general adjustment for contingencies, the possibility of re-partnering will only increase the general adjustment if evidence is presented that increases the possibility of repartnering occurring above the possibility of any of the other general contingencies occurring. The adjustment for general contingencies should at average be below twenty per cent.

Re-partnering will only be regarded as a specific contingency if it has already taken place at the time of quantification. The specific contingency adjustment for re-partnering will be based on the future uncertainty of the effect of the repartnering on the claim for loss of support. The future uncertainty refers inter alia to the lifetime of the new relationship and the financial position of the new partner. The extent of the adjustment for this specific contingency will be determined by the specific evidence presented to court.

If these guidelines are followed it will limit to a certain extent the discretion of the court in quantifying the claim for loss of support.

established rule that, in a wrongful death action, the court must assess and value the chance of the surviving spouse obtaining financial support in the future from remarriage. Nor should the Court abolish the more recent rule that support from a de facto relationship is a matter that may be assessed and valued. Moreover, I see no advantage in subsuming the discount for future support under the rubric of general contingencies." Also see the minority judgment of Callinan J in De Sales v Ingrilli [2002] 212 CLR 338 (HC) 407. 


\section{Bibliography}

Atkinson 2003 QUTLJJ

Atkinson R "Women and justice - Is there justice for women?" 2003

Queensland University of Technology Law \& Justice Journal 1-10

\section{Boberg 1964 SALJ}

Boberg PQR "Deductions from gross damages in actions for wrongful death" 1964 South African Law Journal 194-225

Carver 2005 QUTLJJ

Carver $\mathrm{T}$ "Through the looking glass: Wrongful death, remarriage and Australian law reform" 2005 Queensland University of Technology Law \& Justice Journal 1-27

Davel Afhanklikes

Davel T Skadevergoeding aan Afhanklikes (Digma-Publikasies Roodepoort 1987)

Davel 1989 De Jure

Davel T "Senior v National Employers General Isurance Co Ltd 19892 SA 136 (W)" 1989 De Jure 365-372

Howroyd and Howroyd 1958 SALJ

Howroyd R and Howroyd FJ "The assessment of compensation for loss of support" 1958 South African Law Journal 65-83

Koch Damages for Lost Income

Koch RJ Damages for Lost Income (Juta Cape Town 1984)

Koch Reduced Utility

Koch RJ The Reduced Utility of a Life Plan (Rustica Press Cape Town 1993) 
Koch 1986 JCRDL

Koch RJ "Damages for personal injury and death" 1986 Journal of Contemporary Roman-Dutch Law 215-224

Luntz Assessment of Damages

Luntz $\mathrm{H}$ Assessment of Damages for Personal Injury and Death $4^{\text {th }}$ ed (Butterworths Sydney 2002)

Luntz and Hambly Torts

Luntz $\mathrm{H}$ and Hambly D Torts: Cases and Commentary $5^{\text {th }}$ ed (LexisNexis

Butterworths Sydney 2006)

Steynberg Gebeurlikhede

Steynberg L Gebeurlikhede in die Deliktuele Skadevergoedingsreg (LL Dthesis UNISA 2006)

Thomson 1988 De Rebus

Thomson RJ "The determination of the deduction for remarriage from the pecuniary loss of a widow" 1988 De Rebus 67-70

Visser and Potgieter Law of Damages

Visser PJ and Potgieter JM (assisted by Steynberg L and Floyd TB) Law of Damages $2^{\text {nd }}$ ed (Juta Cape Town 2003)

\section{Register of cases}

AA Tegel Pty Ltd v Madden [1985] 2 NSWLR 591 (SC)

Amod v Multilateral Motor Vehicle Accident Fund (Commission for Gender

Equality Intervening) 19994 SA 1319 (SCA)

Anthony $v$ Cape Town Municipality 19674 SA 445 (A)

Bester v Silva Fishing Corporation (Pty) Ltd 19521 SA 589 (C)

Budget Rent-A-Car Systems Pty Ltd v Van der Kemp [1984] 3 NSWLR 303

Burns v National Employers General Insurance Co Ltd 19883 SA 355 (C)

Chisholm v East Rand Proprietary Mines Ltd 1909 TH 297 
Clair v Port Elizabeth Harbour Board 1886 EDC 311318

Constantia Versekeringsmaatskappy Bpk v Victor 19861 SA 601 (A)

Cooke and Cooke v Maxwell 1942 SR 133

Cremona v RTA [2000] NSWSC 556 par 64

De Jongh v Gunther 19754 SA 78 (W)

De Sales v Ingrilli [2002] 212 CLR 338 (HC)

De Wet v Odendaal 1936 CPD 103

Dominish v Astill [1979] 2 NSWLR 368

Du Plessis v Road Accident Fund 20041 SA 359 (SCA)

Du Toit v Minister of Welfare and Population Development 20032 SA 198 (CC)

Faulkner v Keffalinos [1970] 45 ALJR 80 (HC)

Glass v Santam Insurance Ltd 19921 SA 901 (W)

Goodburn v Thomas Cotton Ltd [1968] 1 QB 845 (CA)

Herman v Johnston [1972] WAR 121

Hewitt v Tonkin [2003] WADC 203 par [21] (unreported, 29 September 2003)

Hollebone v Greenwood (1968) 71 SR (NSW) 424 (CA)

Hulley v Cox 1923 AD 234

$\mathrm{J}$ and another $v$ Director General, Department of Home Affairs 20035 BCLR $463(\mathrm{CC})$

Jones v Schiffmann [1971] 124 CLR $303(\mathrm{HC})$

Kennedy v Port Elizabeth Harbour Board (1886) 5 EDC 311

Knight $v$ Anderson (1997) 17 WAR 85

Kuhlewein v Fowke [2000] QSC 404 (unreported, 10 November 2000)

Lamb v Brandt [1984] 56 BCLR 74 (CA)

Lebona v President Versekeringsmaatskappy Bpk 19913 SA 395 (W)

Legal Insurance Company Ltd v Botes 19631 SA 608 (A)

Mahoney v Dewinter (unreported, Supreme Court of Queensland, Court of

Appeal, 15 March 1993)

Marine and Trade Insurance Co Ltd v Katz 19794 SA 961 (A)

Masiba v Constantia Insurance Co Ltd 19824 SA 333 (C)

McIntosh v Williams [1979] 2 NSWLR 543 (SC)

Milns v Protea Assurance Co Ltd 19783 SA 1006 (C)

Mlisane v South African Eagle Insurance Co Ltd 19963 SA 36 (C)

Munarin v Peri-Urban Areas Health Board 19651 SA 545 (W) 
Nochomowitz v Santam Insurance Co Ltd 19721 SA 718 (T)

Ongevallekommissaris v Santam Bpk 19991 SA 251 (SCA)

Parity Insurance Co Ltd v Van den Bergh 19664 SA 463 (A)

Paterson v South African Railways and Harbours 1931 CPD 289

Peri-Urban Areas Health Board v Munarin 19653 SA 367 (A)

Public Trustee v Paniens [1971] 1 SASR 297 (SC)

Roberts v London Assurance Co Ltd (3) 19482 SA 841 (W)

Robinson v Volks [2004] 2 All SA 61 (C)

Rodda $v$ Boontjie Pty Ltd (unreported, Supreme Court of Queensland, 27 May 1993)

Santam Bpk v Henery 19993 SA 421 (A)

Santam Insurance Co Ltd v Fourie 19971 SA 611 (A)

Satchwell v President of the Republic of South Africa 20026 SA 1 (CC)

Shield Insurance Co Ltd v Booysen 19793 SA 953 (A)

Smart v SAR\&H 1928 NPD 361

Snyders v Groenewald 19663 SA 785 (C)

Trimmel v Williams 19523 SA 786 (C)

Waring \& Gillow Ltd v Sherborne 1904 TS 340

Willis $v$ The Commonwealth (1946) 73 CLR 105

Zimnat Insurance Co Ltd v Chawanda 19912 SA 825 (ZS)

\section{Register of legislation}

Acts Amendment (Equality of Status) Act 2003 (Western Australia)

Black Laws Amendment Act 76 of 1963

Civil Law (Wrongs) Act 2002 (Australian Capital Territory)

Civil Liability Act 1936 (Southern Australia)

Civil Unions Act 17 of 2006

Compensation (Fatal Injuries) Act 1974 (Northern Territories)

Compensation to Relatives Act 1897 (New South Wales)

Constitution of the Republic of South Africa 1996

Discrimination Law Amendment Act 2002 (Queensland)

Fatal Accidents Act 1934 (Tasmania)

Fatal Accidents Act 1950 (Western Australia) 
Fatal Accidents Act 1976 (England)

Law Reform (Gender, Sexuality and De facto Relationships Act 2003 (Northern Territory)

Property (Relationships) Legislation Amendment Act 1999 (New South Wales)

Recognition of Customary Marriages Act 120 of 1998

Relationships (Consequential Amendments) Act 2003 (Tasmania)

Supreme Court Act 1995 (Queensland)

Wrongs (Dependants) Act 1982 (Victoria)

Wrongs Act 1958 (Victoria)

\section{List of abbreviations}

ch chapter(s)

par paragraph(s)

$\mathrm{s} \quad$ section(s)

subs subsection(s) 